\title{
TINGKAT KETAATAN SISWA DALAM MENJALANKAN IBADAH DI SMP NEGERI 3 TURI SLEMAN
}

\author{
Siti Aminah \\ Program Pasca Sarjana \\ Universitas Muhammadiyah Yogyakarta \\ E-mail: $\underline{\text { staminah03@gmail.com }}$
}

\begin{abstract}
Abstrak
Tujuan dalam penelitian ini untuk mengetahui tingkat ketaatan beribadah, kemudian program sekolah yang mendorong peningkatan ketaatan beribadah siswa serta faktor yang mempengaruhi tingkat ketaatan beribadah siswa di SMP Negeri 3 Turi. Jenis penelitian yang digunakan adalah deskriptif kualitatif, dengan sampel penelitian sebanyak 24 siswa kelas VIII. Teknik pengumpulan data menggunakan angket, wawancara dan observasi. Sedangkan analisis data menggunakan reduksi data, display dan verifikasi data atau kesimpulan. Adapun hasil dari penelitian ini adalah 1) Ketaatan Beribadah di SMP Negeri 3 Turi meliputi a) ketaatan dalam ibadah shalat yang meliputi ibadah shalat wajib, shalat sunah dhuha, shalat berjama'ah, dan shalat tarawih; b) ketaatan dalam ibadah puasa meliputi puasa wajib, puasa senin kamis, puasa syawal, puasa arofah dan puasa daud; c) ketaatan dalam doa dan dzikir meliputi berdoa setelah shalat dan membaca al-Qur'an. 2) Program sekolah yang mendukung ketaatan beribadah meliputi tadarus sebelum pelajaran, kegiatan sosial-keagamaan dan pengajian kelas. c) Factor yang mempengaruhi ketaatan beribadah siswa adalah motivasi orang tua, pemantauan guru, pergaulan teman sebaya dan kegiatan lingkungan masyarakat

Kata kunci: ketaatan siswa, ibadah, siswa SMP
\end{abstract}

\begin{abstract}
The purpose of this study was to determine the level of observance of worship, then school programs that encourage increased observance of student worship as well as factors that affect the level of observance of students in SMP Negeri 3 Turi. This type of research is descriptive qualitative, with a sample of 24 students of class VIII. Data collection techniques using questionnaires, interviews and observations. While data analysis uses data reduction, display and data verification or conclusions. The results of this study are 1) Compliance for worship in SMP Negeri 3 Turi includes a) observance in the worship of prayer which includes compulsory worship, dahuha prayer, congregational prayer, and tarawih prayer; $b$ ) observance in fasting includes compulsory fasting, monday fasting thursday, fasting Shawwal, fasting arofah and fasting daud; c) observance in prayer and dhikr includes praying after prayer and reading the Qur'an. 2) School programs that support observance of worship include pre-lesson schedules, socio-religious activities and class studies. c) Factors that influence student observance are parents' motivation, teacher monitoring, peer grouping and community environmental activities Keywords: student obedience, worship, junior high students
\end{abstract}

\section{Info Artikel}

Diterima Januari 2020, disetujui Februari 2020, diterbitkan Juni 2020 


\section{PENDAHULUAN}

Pendidikan Agama Islam merupakan satu diantara sarana pembudayaan (enkulturasi) masyarakat. Sebagai suatu sarana, pendidikan dapat difungsikan untuk mengarahkan pertumbuhan dan perkembangan hidup manusia, (sebagai makhluk pribadi dan sosial) kepada titik optimal kemampuan untuk memperoleh kesejahteraan hidup di dunia dan kebahagiaan hidup di akhirat. Nabi Muhammad SAW. diutus oleh Allah salah satu tujuannya untuk memperbaiki keadaan umat dengan ajaran Agama Islam. Rasulullah SAW sebagai pelaksana pendidikan Islam secara umum menuntun umat dari kegelapan menuju jalan yang terang. Pendidikan Agama Islam berfungsi mengarahkan perkembangan hidup manusia, maka dari itu dalam hal ini dibutuhkan kegiatan yang nyata seperti efektifitas Pendidikan Agama Islam itu sendiri pada aspek ibadah. Efektifitas berarti menunjukkan tercapainya suatu tujuan, suatu usaha dikatakan efektif apabila usaha itu telah mencapai tujuannya.

Ibadah merupakan salah satu pelajaran yang dapat diambil dalam Pendidikan Agama Islam, Ibnu Taimiyah mengartikan ibadah adalah ketaatan dan ketundukan yang sempurna dengan rasa cinta kepada yang disembah untuk mencapai keridaan-Nya dan mengharap imbalan pahala di akhirat kelak. Allah menciptakan manusia hanya untuk beribadah kepada-Nya. Dalam rangka ibadah kepada Allah, manusia telah diberi petunjuk oleh-Nya. Petunjuk Allah tersebut dinamakan Ad-Din (agama). Agama adalah satu kata yang sangat mudah diucapkan dan mudah juga untuk menjelaskan maksudnya (khususnya bagi orang awam), tetapi sangat sulit memberikan batasan (definisi) yang tepat lebih-lebih bagi para pakar.

Secara filosofis, ibadah dalam Islam tidak semata-mata bertujuan untuk menyembah Allah Sebab, disembah atau tidak disembah, Allah tetaplah Allah Esensi ketuhanan Allah tidak pernah berkurang sedikit pun apabila manusia dan seluruh makhluk di jagat raya ini tidak menyembah-Nya. Ibadah merupakan upaya mendekatkan diri kepada Allah. Allah adalah eksistensi Yang Maha Suci yang tidak dapat didekati kecuali oleh yang suci. Diakui oleh para ulama dan para peneliti atau pakar, bahwa salah satu ibadah yang sangat penting dalam Islam adalah shalat. Shalat memiliki kedudukan istimewa baik dilihat dari cara memperoleh perintahnya yang dilakukan secara langsung, kedudukan shalat itu sendiri dalam agama maupun dampak atau fadilahnya. Kedudukan shalat dalam agama Islam sebagai ibadah yang menempati 
posisi penting yang tidak dapat digantikan oleh ibadah apa pun juga, shalat merupakan tiang agama yang tidak akan dapat tegak kecuali dengan shalat. Shalat adalah ibadah yang pertama kali diwajibkan oleh Allah kepada hamba-Nya, perintah kewajibannya disampaikan langsung oleh Allah melalui dialog dengan Rasul-Nya pada malam Mi'raj. Shalat juga merupakan amalan yang mula-mula akan dihisab.

Ibadah adalah sebagai sarana penghubung antara hamba dengan Tuhannya. Mendirikan shalat berarti mencerminkan keimanan sebagai tanda syiar agama dan sebagai tanda syukur kepada Allah. Meninggalkan shalat berarti memutuskan tali penghubung dengan Allah, berakibat tertutupnya rahmat dari-Nya, terhentinya pengaliran nikmat-nikmat-Nya, terhentiny suluran kebaikan-Nya dan berarti juga mengingkari fadhol (keutamaan) dan kebesaran Allah. Kewajiban shalat termasuk ke dalam salah satu rukun Islam, diwajibkan ketika Rasulullah SAW mi'raj. Tetapi kewajiban shalat yang merupakan rukun Islam ini sering diabaikan dan dianggap tidak penting, hal ini dapat dilihat dengan masih banyaknya manusia yang tidak mengerjakan shalat.

Di sekolah banyak para siswa yang kurang sadar akan kewajiban melaksanakan shalat sertabanyak pula yang sudah sadar namun kurang disiplin dalam melaksanakan shalat. Seperti pengalaman yang didapat oleh peneliti selama berkunjung ke beberapa sekolah, peneliti mendapatkan banyak siswa yang belum memiliki kesadaran dalam melaksanakan ibadah. Guru yang merupakan pembimbing mereka di sekolah pun sering kali tidak didengar nasehatnya agar mereka tidak meninggalkan shalat. Hal itu menunjukkan seakan-akan mereka tidak takut dengan keberadaan Allah yang selalu megawasi makhluk-Nya di muka bumi ini. Berdasarkan latar belakang masalah di atas penulis tertarik untuk melakukan penelitian lebih mendalam tentang tingkat ketaatan pelaksanaan ibadah yang meliputi ibadah shalat, puasa dan membaca al-Qur'an.

\section{METODE PENELITIAN}

Jenis penelitian yang dilakukan oleh penulis adalah lapangan (field research), dengan menggunakan jenis penelitian utamanya adalah kualitatif deskriptif. Penelitian kualitatif merupakan penelitian yang bermaksud untuk memahami fenomena tentang apa yang dialami oleh subyek penelitian misalnya perilaku, persepsi, motivasi, tindakan, dan lain-lain, secara holistik, dan dengan cara deskripsi dalam bentuk kata-kata dan 
bahasa, pada suatu konteks khusus yang alamiah dan dengan memanfaatkan berbagai metode alamiah.

Tempat penelitian adalah SMP Negeri 3 Turi Kabupaten Sleman. Waktu penelitian adalah bulan April-Juni 2018. Sedangkan sampel dalam penelitian ini sebanyak 24 siswa kelas VIII. Teknik pengumpulan data menggunakan angket, wawancara dan observasi. Sedangkan analisis data menggunakan reduksi data, display dan verifikasi data atau kesimpulan.

\section{HASIL DAN PEMBAHASAN}

\section{Tingkat Ketaatan dalam Ibadah}

Fokus dalam ibadah dalam penelitian ini meliputi ibadah shalat (yang terdiri dari shalat 5 waktu, shalat berjama'ah, shalat dhuha dan shalat tarawih), ibadah puasa (yang meliputi puasa wajib ramadhan, puasa sunah senin-kamis, 6 hari di bulan syawal, puasa arofah dan puasa daud) serta ibadah doa dan dzikir. Berdasarkan hasil penelitian tingkat kesadaran ibadah siswa di SMP Negeri 3 Turi dapat disimpulkan seperti dalam diagram berikut ini:

Tabel 1. Tingkat Kesadaran Ibadah Siswa di SMP Negeri 3 Turi

\begin{tabular}{|c|l|c|c|}
\hline No & \multicolumn{1}{|c|}{ Indikator } & Persentase & Rata-rata \\
\hline 1 & Ketaatan Shalat & 72.92 & \multirow{2}{*}{71.08} \\
\cline { 1 - 3 } 2 & Ketaatan Puasa & 62.71 & \multirow{2}{*}{77.60} \\
\cline { 1 - 3 } 3 & Ketaatan Doa dan Dzikir & \\
\hline
\end{tabular}

Berdasarkan tabel di atas dapat dijelaskan bahwa tingkat ketaatan beribadah siswa SMP Negeri 3 Turi termasuk kategori Baik $(71,08 \%)$.

\section{Program Sekolah yang Mendukung Peningkatkan Ketaatan Beribadah Siswa}

Program sekolah yang mendukung peningkatan ketaatan ibadah di SMP Negeri 3 Turi meliputi tadarus Al-Qur'an sebelum pelaksanaan pembelajaran, aktif dalam kegiatan sosial-keagamaan, pengajian kelas secara rutin setiap bulan.

\section{Faktor yang Mempengaruhi Ketaatan Beribadah Siswa}

Dalam melakukan sebuah aktivitas seseorang tidak lepas dari dua faktor, yaitu intrinsik dan ekstrinsik. Berdasarkan pembahasan mengenai faktor yang mempengaruhi 
motivasi beribadah SMP Negeri 3 Turi dapat disimpulkan bahwa faktor yang mempengaruhi ketaatan beribadah adalah motivasi orang tua, kedisiplinan guru, pergaulan teman sebaya dan kegiatan keagamaan di lingkungan tempat tinggal.

\section{KESIMPULAN}

Dari hasil kajian yang telah dilakukan oleh peneliti, maka penelitian ini menyimpulkan sebagai berikut:

a. Ketaatan Beribadah di SMP Negeri 3 Turi meliputi a) ketaatan dalam ibadah shalat yang meliputi ibadah shalat wajib, shalat sunah dhuha, shalat berjama'ah, dan shalat tarawih; b) ketaatan dalam ibadah puasa meliputi puasa wajib, puasa senin kamis, puasa syawal, puasa arofah dan puasa daud; c) ketaatan dalam doa dan dzikir meliputi berdoa setelah shalat dan membaca al-Qur'an.

b. Program sekolah yang mendukung ketaatan beribadah meliputi tadarus sebelum pelajaran, kegiatan sosial-keagamaan dan pengajian kelas.

c. Factor yang mempengaruhi ketaatan beribadah siswa adalah motivasi orang tua, pemantauan guru, pergaulan teman sebaya dan kegiatan lingkungan masyarakat.

\section{DAFTAR PUSTAKA}

Al-Shawaf, A. M. M. 1995. Pengajaran Shalat Lengkap. Semarang: Dina Utama Semarang.

Rachman, B. M. Ensiklopedi Nurcholis Madjid. Jilid 1. Ebook/Edisi Digital.

Lexy J. Moleong, L. J. 2001. Metodologi Penelitian Kualitatif. Bandung: Remaja Rosda Karya.

Uhbiyati, N. 1999. Ilmu Pendidikan Islam. Bandung: Pustaka Setia.

Shihab, Q. 1994. Membumikan Al-Qur'an. Bandung: Mizan.

Stark, R., dan C. Y. Glock, C. Y. 1988. “Dimensi-dimensi Keberagamaan”. dalam Roland Robertson (ed), Agama dalam Analisis dan Interpretasi Sosiologis. Terj. dari Sosiology of Religion oleh Achmad Fedyani Saifuddin. Jakarta: Rajawali.

Ramayulis. 2002. Psikologi Agama. Jakarta: Kalam Mulia.

Tim Penyusun Kamus Pusat Pembinaan dan Pengembangan Bahasa. 1988. Kamus Besar Bahasa Indonesia. Jakarta: Balai Pustaka. 